\title{
Urban land reform in South Africa: Pointers for urban policy and planning
}

\section{Marie Huchzermeyer, Philip Harrison, Sarah Charlton, Neil Klug, Margot Rubin \& Alison Todes}

DOI: http://dx.doi.org/10.18820/2415-0495/trp75i1.10

Peer reviewed and revised October 2019; Published December 2019

*The authors declared no conflict of interest for this title or article

\begin{abstract}
Urban and reform is a relatively under-researched and -considered element of the broader land-reform debate. This article reviews some of the key positions that have been explicated in the current urban land-reform debate, and seeks to extend existing contributions, fine-tune them and push the debate further. It does so by distinguishing the features of urban land, and considers these and their implications for the meaning of land reform. It also reviews the recently achieved, national policy consensus on urban development and planning, and concludes with suggestions on how to proceed with urban land reform.
\end{abstract}

Keywords: Land reform, land tenure, planning, policy, South Africa, urban

\section{STEDELIKE GRONDHERVORMING IN SUID-AFRIKA: WENKE VIR STEDELIKE BELEID EN BEPLANNING}

Daar is relatief min navorsing gedoen rondom stedelike grondhervorming binne die groter grondhervormingsdebat. Hierdie artikel ondersoek hoofuitgangspunte wat die grondhervormingsgesprek dryf. Die skrywers ontwikkel ook bestaande bydraes om die debat te verbreed. Dit word gedoen deur onderskeiding van die kenmerke van stedelike grondbesit, en oorweeg hierdie eienskappe in terme van die implikasies wat hulle het op grondhervorming. Dit hersien ook, wat mees onlangs in hierdie gebied bereik is, die nasionale konsensus oor grondhervorming en beplanning en sluit af met voorstelle hoe die proses van stedelike grondhervorming vorentoe geneem kan word.

Sleutelwoorde: beleid, beplanning, grondbesit, grondhervorming, stedelik, Suid-Afrika

\section{NTLAFATSO LEFATSHENG LA LITOROPO TSA AFRIKA BORWA: LINTLHA MOLEMONG OA MAANO LE THERO}

Boithuto bo amanang le phetoho lefatsheng la litoropo bo tlase haholo le hoja taba ea phetoho ea leffatshe ka kakaretso e lula ele melomong ea batho. Sengoliloeng sena se lekola tse ling tsa linthla-kemo tse hlahisitsoeng ke lipuisano holima phetoho ea lefatshe la litoropo, 'me e ntshetsa pele maikutlo a teng ele ho tsoelisa lipuisano pele. Sena se etsoa ka ho hlalohanya semelo sa lefatshe la litoropo, le ho hlahloba litla-morao tse ka tlisoang ke kutloisiso e batsi ea phetoho ea lefatshe. Boithuto bona bo boetse bo lekola molao le meralo e mecha ea lefatshe ea naha, mme e phethela ka likeletso tse ka tsoelisang naha pele nthleng ena ea phetoho ea lefatshe.

\section{INTRODUCTION}

The South African land-reform initiative has largely centred on rural or commercial farming contexts. Given the scale of racially based land dispossession under segregationist and apartheid rule, land reform has centred on the transfer of land from White to Black ownership through restitution and redistribution processes. However, there are concerns over its slow pace (Kepe \& Hall, 2016; Hornby, Kingwell, Royston \& Cousins, 2017). Landtenure reform is a third mechanism, focusing on securing and protecting customary and informal land rights (Kepe \& Hall, 2016). This has not involved changes to the institution of private property as the dominant form of holding rights to land, often considered as most secure (Van der Walt, 2009).

The explicit notion of 'urban land reform' has only recently received attention in the post-apartheid policy agenda (RSA, 2019: 88). Nevertheless, urban land restitution has involved high-profile and ambitious cases such as District Six, bordering Cape Town's central business district (Beyers, 2013: 980). The urban restitution

Prof. Marie (MH) Huchzermeyer, Convenor: Master of Urban Studies, School of Architecture and Planning, University of the Witwatersrand, Private Bag 3, Wits 2050. Phone: +27-11-7177688, e-mail: <marie.huchzermeyer@wits.ac.za>

Prof. Philip (PJ) Harrison, South African Research Chair in Spatial Analysis and City Planning, School of Architecture and Planning, University of the Witwatersrand, Private Bag 3, Wits 2050. Phone: +27-11-7177646, e-mail: <philip.harrison@wits.ac.za>

Assoc. Prof. Sarah Charlton, Associate Director: CUBES (Centre for Urbanism and Built Environment Studies), School of Architecture and Planning, University of the Witwatersrand, Private Bag 3, Wits 2050. Phone: +27 117177717 , e-mail: <sarah.charlton@wits.ac.za>

Mr Neil (NC) Klug, Senior Lecturer, School of Architecture and Planning, University of the Witwatersrand, Private Bag 3, Wits 2050. Phone: +27-11-7177729, e-mail: <neil.klug@wits.ac.za>

Dr Margot Rubin, Senior Lecturer, School of Architecture and Planning, University of the Witwatersrand, Private Bag 3, Wits 2050. Phone: +27-11-7177646, e-mail: <margot.rubin@wits.ac.za>

Prof. Alison (AE) Todes, Professor of Urban and Regional Planning, School of Architecture and Planning, University of the Witwatersrand, Private Bag 3, Wits 2050. Phone: +27-11-7177702, e-mail: <alison.todes@wits.ac.za> 
processes have been "exceedingly long and arduous" (some lasting over 15 years), and have largely missed the strategic potential of intervening in the urban property regime, as most of the claims were settled through compensation (Beyers, 2013: 986). In 2015, the South African Cities Network (SACN) found the urban land debate "one of the most neglected but influential issues in post-apartheid South Africa" (SACN, 2015: 3). In South Africa, with $64 \%$ of the population already living in urban areas, ${ }^{1}$ including $44.2 \%$ of those living below the Upper Bound Poverty Line (UBPL) (Stats SA, 2017), an urban focus in the land-reform debate is indeed appropriate and overdue.

This article makes a case for urban land reform and argues that it is necessary to start from an understanding of the significance of urban land, rather than simply transposing concepts and debates from the rural context. It is also important to understand how the patterns of access and use of urban land are the outcome of historically layered intersections between state policy and the operation of the market. From this perspective of 'political economy', urban land reform requires political will to address the entrenched interests in the current spatial order and social mobilisation in support of the process. However, an urban land-reform agenda must be supported by an appropriate set of instruments, interventions and plans, as discussed in this article.

In early $19^{\text {th }}$ century Europe, land reform was thought to be "a viable strategy to resolve poverty and 'the social question'"; at the time, some considered it a "third way" between communism and capitalism (Davy, 2009: 252). Some early European and North American proponents of land reform for non-agricultural purposes sought alternatives to private property, an institution which, in their understanding, contributed to

1 Defined by Stats SA (2010: 119) as "formal cities and towns characterised by higher population densities, high levels of economic activities and high levels of infrastructure". poverty and inequality (Davy, 2009).

One of these early proponents,

Ebenezer Howard, advocated for "the ownership of the Garden City's land by a board of trustees" (Davy, 2009: 253). Howard was also one of Britain's most influential town planners of the late $19^{\text {th }}$ and early $20^{\text {th }}$ century. A close association between the ideals of both land policy and planning stems from this time. However, the achievement of land reform through, or in close association with planning has been compromised by the uneven success of urban planning (Watson, 2009). In South Africa, urban land reform is burdened by high levels of wealth inequality, with "at least half" of South Africa's wealth estimated to be owned by "one percent of South Africans", $90 \%$ to $95 \%$ owned by the wealthiest $10 \%$ (Orthopher, 2016: 23). A further challenge for urban land reform is that wealth is partly vested in urban real estate, which ties the fate of urban land directly to the functioning of an important part of the economy.

This article briefly reviews positions in the current urban land-reform debate in South Africa, with a view to underline, fine-tune and extend existing contributions. Although the rural and the urban in South Africa are conjoined in multiple ways, urban land has distinguishing features. The article reviews these because of their implications for the meaning of land reform. Further, it reviews the recently achieved national policy consensus on urban development and planning, which provides a platform for integrating land into a wider urban reform programme. The article makes suggestions on how to proceed with urban land reform, including implications for planning.

\section{CURRENT POSITIONS IN THE URBAN LAND- REFORM DEBATE IN SOUTH AFRICA}

A range of approaches to urban land reform emerged politically and through policy think-tanks and institutes in 2018, with academics contributing to these deliberations. The position of the Economic Freedom Fighters (EFF) is considerably far-reaching. In practice, this political party has instigated "extrajudicial land occupations in urban areas" as a process of de facto urban land reform from below (Mpofu, 2017: 96), the media framing this as "land grabs" (BusinessTech, 2018a: online). The EFF also has the stated intention of transferring all land into "the ownership and custodianship of the state", without disrupting existing residential rights. It intends to allocate and manage land use through timebound leases of up to a maximum of 30 years to ensure "a balanced land allocation for residential purposes" and to enable the state to "build low cost housing in areas previously seen as enclaves of whites and the rich" (Morapela, 2018: 17, 21). The EFF also promotes democratisation of the administration of land held in customary tenure, so as to ensure participatory decisionmaking inclusive of women (Morapela, 2018: 28). Given the overlap between land held in this form and urban areas, for instance in eThekwini/Durban, this is also a facet of the EFF's position on urban land reform.

By contrast, the Democratic Alliance (DA) understands "[p]roperty rights [as] the bedrock of development and economic growth" and is opposed to any tampering with this institution in law (BusinessTech, 2018b: online, quoting DA leader Mmusi Maimane). This political party argues that the slow progress on land reform is not a constitutional problem; it can rather be blamed on poor implementation, maladministration and corruption (DA, [n.d.]). The approach of the ruling African National Congress (ANC) is aligned to the existing legal and policy framework of subsidising the redistribution of urban land largely under freehold title, but with the intention of accelerating this. In August 2018, the Gauteng provincial leadership of the ANC responded to the resolution on land reform at the ANC's December 2017 Policy Conference, by reviving an erstwhile rapid land-release initiative that had 
attempted to fast-track land access to the poor, but with limited success (Bremner, 2000; Nicolson, 2018).

The Helen Suzman Foundation, which "promotes liberal constitutional democracy and rule of law" (HSF, n.d.: online), places Gauteng's rapid land-release initiative within this context, by reviewing a wide range of human settlement policy instruments, including sites and service schemes (Simkins \& Fonkam, 2018). The Socio-Economic Rights Institute of South Africa (SERI), a human rights organisation focusing on public interest law, in turn, calls for an urban land-reform programme centring on the most disadvantaged, thus prioritising the upgrading of informal settlements through an approach that recognises existing "local norms, practices and agency" (Royston \& Ebrahim, 2019: online). The SACN (2015), a network of municipalities, draws on a range of academic contributors in articulating urban land concerns with spatial transformation and with the planning framework. Despite these different orientations and dimensions in the urban land-reform debate, there is a unified argument for an expedited urban land-reform programme across these positions.

Importantly, the significance of the urban dimension within land reform was raised in the report of the Expert Advisory Panel on Land Reform and Agriculture, which was released in its final version in July 2019 (RSA, 2019). The report followed a consultative process that engaged with the positions and contributions outlined earlier. Its recommendations are at a high level, relating to policy consolidation, the resourcing of land reform, and institutional change, including the creation of a consolidated land-information system. In relation to urban land reform, it recommends the formulation of an urban land-reform policy, the fostering of more equitable urban spatial patterns, the targeted use of stateowned land, the recognition of diverse forms of tenure rights, including off-register rights, and actions to give meaning to the notion of equitable access derived from Section 25.5 of the Constitution, to which we return below. These include proactive steps such as vacant land release, as well as recognition and protection, where possible, of existing land and building occupations (RSA, 2019). This article draws from and builds on inputs made to the Panel by the authors as a team in the School of Architecture and Planning at the University of the Witwatersrand. This article mainly follows on from the recommendations of the Panel, arguing for urban land reform as a critical intervention, but adds the need to moderate the interests vested in property, and introduces the notion of 'fair share' in spatial transformation. It also makes a range of specific recommendations on rental accommodation, collective forms of tenure, and the inclusion of land uses beyond the residential in notions of land reform.

\section{THE DISTINGUISHING CHARACTERISTICS OF URBAN LAND}

While one cannot separate the rural and the urban categorically, there are features that apply distinctly to urban land, and that an urban land-reform debate must recognise. Mkhize (2015: 3) highlights the intensity and diversity of "economic productivity, geographic location, ecological features, infrastructural capacity and socio-political dynamics" of urban land, adding that, in South African cities, the historical pattern of residential settlement, coupled with land regulations, has manufactured a land scarcity and, therefore, exclusion. SACN (2015) points to the significant capital invested in urban land, thus contributing, through the property market, to economic growth. The property sector, as a vehicle for accumulation, functions according to market-based rules, which exclude those who cannot afford to participate. This is a key concern of urban land reform.

Progressively, over time, the operation of the urban land market works to displace the poor to increasingly marginal parts of the city. Government interventions to counter this trend have seldom realised the intended results. As Davy (2009: 240) notes in a review of different planning approaches, "the predominance of private property rights" is not easily disrupted. He further notes that "[p]lanning as moderation of property neither facilitates social reform nor does it satisfy every member of the community's demand for full social citizenship". Where urban land markets are moderated by planning, the location of urban land remains a critical factor in shaping its value. Bid rent theory, first developed in 1960 , but still used in present-day urban analyses (Guo, Buchmann \& Schwarz, 2019), shows how urban land markets operate in exclusionary ways, as the wealthier are able to outbid the poorer for the better urban locations. Restrictions in access to finance play a compounding role in this spatial exclusion. However, there are also relationships between land prices, location, access, and density (Bertaud, 2015). In spatial terms, the functioning of the bid rent curve is not simple. The curve was initially modelled on the idea of the Central Business District (CBD) as the most accessible and desirable place in the city attracting the highest land rents. Globally, the trend has been for city form to become more multi-nodal over time (Watson, 2009). Locations that were once spatially marginal may now be highly desirable in economic and residential terms for particular interests. However, forms of bid rent and the exclusion associated with land markets still operate in these contexts.

In South Africa, deliberate racial segregation through spatial planning forced distinct lines or barriers of exclusion. Apartheid-based zoning further determined land value by prescribing the size of land parcels, land use and building standards differentiated by racial designations (Harrison, Todes \& Watson, 2008). Post-apartheid planning has failed to redress this situation, with land values still reflecting the effects of the apartheid city and racialised spatial inequalities. While there has been some movement of Black people into former White areas with high 
land values, this has been limited by economic inequalities; resistance by middle-class communities to perceived low-income developments and informal housing in their suburbs; the lack of government low-income and social housing projects in these areas, and, more generally, land costs that affect the viability of developments aimed at low-income housing. Massyn, McGaffin, Viruly and Hopkins (2015) argue that, in Cape Town, land costs are too high for developers to produce even low-middle income housing in well-located areas.

There are other ways of conceiving of the value of land apart from monetary value. Proponents of fairer neighbourhoods and cities have long promoted the notion of use value over that of exchange or commodity value (Lefebvre, 1996/1968). More recently, through the promotion of Brazilian constitutional advances, the 'social function' of human settlements and of land has gained recognition. This concept refers to "the extent to which a property holder should be able to enjoy his property regardless of social deprivation and environmental degradation" (Cities Alliance, 2010: 16). In Brazil, it was put into practice (with mixed results) through instruments such as progressive land taxation and compulsory subdivision in accordance with a collectively defined masterplan and through increased powers given to municipalities in its implementation (Cities Alliance, 2010: 16). The notions of use value and of the social function of land have been used to legitimise informal urban land occupation by poor households and to secure their tenure (Fernandes, 2002). Through advocacy of the global right to the city movement, 'social function' has found its way into the New Urban Agenda, alongside that of an "ecological function of land" (Habitat III, 2016: S13a, 69). Other terms that describe dimensions of non-monetary value of land are 'lived value', 'cultural value', and 'ecological value' (Weber, 2002; Li, Li \& Qian, 2010). These are important alternative perspectives, but whether interventions in urban land markets are able to prevent the exchange value of land dictating the place of the urban poor in the city is a key question for urban land reform. Land in the city must also be recognised as an asset that leverages additional value, with ownership passed down generations, accumulating intergenerational wealth. In South Africa, this function of urban land needs to be given careful attention, as asset-based inequality is far more extreme than income inequality, with a Gini coefficient of 0.95 for assets compared with 0.64 for income (Orthopher, 2016).

For urban households and individuals, it is not the land itself that provides livelihood, but the proximity to jobs and other livelihood support. The overwhelming bulk of economic activity in urban areas is in secondary and tertiary sectors and is not derived directly from the land such as agriculture and mining. Indeed, urban land forms part of a complex urban system, and it is not practically possible to separate an urban land programme from the other dimensions of urban development which include, for example, networked infrastructure, mobility flows, social infrastructure, urban economy, and urban governance. This point can also be made in relation to rural areas, as parts of the previous homelands are densely populated and are supported economically by remittances from urban areas and local service activity rather than by agriculture (NPC, 2012). However, the concentration of multiple dimensions of urban development produces a qualitative difference for residents of urban as opposed to rural areas. In 2012, the National Planning Commission (NPC) found that "a complex network of towns and cities ... generates about 85 percent of all economic activity" (NPC, 2012: 266). The mainly urban province of Gauteng, for example, covers only $1.49 \%$ of the total national land area, but it accounts for over $25 \%$ of the population and $34.7 \%$ of the national GDP (South African Market Insights, 2019, with reference to population density calculated from the General Household Survey of 2017). The benefits of urban living come from density: this intensity and agglomeration produces the dividends or benefits of 'the urban', including the economies of scale that support the production of jobs, high-order services, innovation, as well as social diversity and vibrancy (Glaeser, 2010).

Access to economic opportunities through housing provision was an intention of the incoming ANC-led government in 1994 (ANC, 1994: 23), which also sought to "break down apartheid geography through land reform, compact cities, decent public transport", and other measures (ANC, 1994: 83). However, the large-scale, state-subsidised housing delivery programme that ensued mostly utilised vacant land on the urban edges, distant from areas of intense economic activity, thus limiting access for its beneficiaries to associated livelihood opportunities. Centre for Affordable Housing Finance in Africa (CAHF) (2019) reports that approximately $30 \%$ of all properties on the title deeds register were financed by government, which amounts to roughly 1888979 properties, signifying an important transfer of assets to some of the poorest households. To a large degree, these properties have not been collateralised to borrow funds for investment in businesses, for instance. Few households are willing to risk losing their only asset, should they be unable to pay back the loan (Marx \& Rubin, 2008). Formation of a property market in these areas has been hampered by commercial banks unable or unwilling to offer mortgages for such properties and to low-income earners (CAHF, 2019). Therefore, not many units have been formally available in the next market segment to offer upward mobility (Shisaka, 2004). This gap in both finance mechanism and housing stock also affects slightly better off households earning too much to qualify for subsidised home ownership, yet unable to acquire a home in the market. As Marais and Cloete (2015) find, the so-called 
'gap market' is inadequately served by the Finance Linked Individual Subsidy Programme (FLISP), which seeks to ease end-user access to mortgages for those who are slightly better off. The unwillingness of banks to mortgage low-cost housing is partly related to its location, in the absence of mechanisms to prevent redlining or spatial discrimination by banks. The use value of such properties is also limited by poor location. Poor or costly transport connections necessitate some beneficiaries to occupy better located urban land informally, in order to access livelihood opportunities. Thus, the mere transfer of urban land assets is not sufficient to promote the ends intended by a land-reform programme, underlining the point that a nuanced understanding of the characteristics of urban land - and particularly its spatial and locational dimensions - must inform such a programme.

\section{NATIONAL CONSENSUS ON URBAN POLICY IN SOUTH AFRICA AS A PLATFORM FOR LAND AND URBAN REFORM}

Almost from the beginning, democratic South Africa has had spatial policies promoting integration, compaction and access, as well as redistribution, but these have been translated rather weakly into regulatory and developmental processes. Arguably, some policy instruments have actively contradicted the visionary spatial policies. An example is the fast-tracking of land-development decisions through provincial tribunals under the Development Facilitation Act of 1995, finally declared unconstitutional in 2010, as it permitted bypassing of the spatial planning function of municipalities. The adoption of a national urban framework and resolving of contradictions in the post-apartheid planning system, as it applied to the approval of urban developments, was delayed in part by a political bias towards rural development. The same bias also shaped the national land-reform initiative (Beyers, 2013). However, in the drafting of the National Development Plan (NDP) leading up to its adoption in 2012, it was evident that a national "consensus [had] begun to emerge around an urban vision for South Africa" (NPC, 2012: 284). Key to this consensus was that urban planning as well as state-subsidised housing delivery had failed to overcome the dysfunctional and unjust apartheid spatial structure, and had instead contributed to its perpetuation (NPC, 2012). The exclusionary nature of the property market is identified as a key contributor to this situation (NPC, 2012: 266). The drafting of the NDP overlapped with the work towards the Spatial Planning and Land Use Management Act of 2013 (SPLUMA) (RSA, 2013), which was only finalised 12 years after the 2001 White Paper. The enactment of SPLUMA was followed by extensive consultations towards the drafting of an Integrated Urban Development Framework (IUDF), the final version adopted in 2015 and published in 2016 (CoGTA, 2016). These three state commitments reinforce one another, the IUDF also forming the basis for the draft 2019 National Spatial Development Framework, which is required as part of the planning framework prescribed by SPLUMA.

The location of national responsibility for planning legislation in the national Department of Rural Development and Land Reform suggests a recognised need for a strong coordination between land reform and urban and regional planning. To date, this has been sought through an inter-ministerial task team rather than restructuring of ministerial portfolios. The NDP identifies a failure in this area of coordination: "Many land-reform initiatives have been in areas that are marginal to markets [not taking] proper account of spatial potentials" (NPC, 2019: 265). The NDP, therefore, calls for a revision of "the land reform programme to incorporate the spatial dimension" (NPC, 2012: 289). This point relates to rural land reform, but the NDP articulates a similar problem with land redistribution in urban areas through the housing subsidy system, for which it identifies "poor spatial targeting" (NPC, 2012: 270). Contributing to the lack of coordination between land reform and planning, the IUDF, which seeks spatial integration, inclusion and access through "inclusive, sustainable economic growth" and capacitated state and citizens (CoGTA, 2016: 8), is located in the national Department of Cooperative Governance and Traditional Affairs (CoGTA). This entity is also responsible for the Local Government: Municipal Systems Act 32 of 2000, which sets out the municipal requirements for Integrated Development Planning (IDP).

The IUDF identifies nine levers through which to achieve the national urban vision: integrated spatial planning; integrated transport and mobility; integrated and sustainable human settlements; integrated urban infrastructure; efficient land governance and management; inclusive economic development; empowered active communities, and effective urban governance (CoGTA, 2016). These indicate a connected package of interventions that are necessary to support the further development of towns and cities towards sustainable outcomes. The lever on land governance and management is of direct relevance to urban land reform. It promotes information on, as well as use and transfer of state-owned land, including land owned by state-owned enterprises (SOEs), and strengthening of the land-use planning and management system along with consistent application of land-related legislation. It encourages effective mechanisms for municipal capture of land value increases that result from public investment, particularly along transit-oriented corridors which it promotes under the levers of integrated transport and mobility, and integrated sustainable human settlements. It also addresses tenure security for the urban poor, requiring the 
system to be clarified and simplified, so as to allow for its acceleration and for incremental approaches. Lastly, it calls for better coordination between municipal and traditional authorities in the management of land and development, where customary areas overlap with municipal boundaries (CoGTA, 2016).

The IUDF lever on integrated human settlements also identifies key priorities that are relevant for urban land reform. It understands the housing function to be best handled at municipal level, which is also where the Constitution and SPLUMA require spatial decisions to be made. The IUDF's integrated human settlements lever calls for support for this through the development of national policy on inclusionary housing. While calling for identification and acceleration of land assembly for integrated human settlement developments, it also highlights opportunities for urban reform and transformation in existing parts of towns and cities that are not fully functional or optimally utilised. It calls for inner city regeneration in a way that focuses on affordable housing that includes the poor. It encourages densification, linking this also to the support required for expansion and improvement of private rental stock in existing residential areas (so-called 'backyarding'). It urges the acceleration of the upgrading of informal settlements, for which existing subsidy and implementation mechanisms are underutilised, and it calls for the redevelopment and improved functional integration of existing townships (CoGTA, 2016).

The IUDF provides a valuable starting point for a multifaceted programme of urban reform that includes a strong element of land reform, but it needs to be taken further. The land reform element could contribute significantly to the proposed "new deal for South Africa's towns and cities" (CoGTA, 2016: 111). The implementation of urban land reform could be further supported by Treasury, with its system of grants to municipalities, in particular through the City Support Programme, which focuses on grant-making to metropolitan municipalities. Chapter Eight of the NDP identified the need for a 'National Spatial Restructuring Fund', possibly consolidating existing built-environment funds, and enabling municipalities to take bolder steps in spatial restructuring (NPC, 2012: 288). Although it calls for a more integrated and improved grant system, the IUDF stops short of taking up this recommendation, which could facilitate costly acquisition of well-located land.

\section{REFINING AND FINE- TUNING PROPOSALS FOR URBAN LAND REFORM}

If land reform is understood to be implemented through three pillars (restitution, redistribution, and securing of tenure), then urban land reform needs to articulate these in relation to the characteristics of urban land and their particularities in the South African context. SPLUMA and the IUDF already form the legal and consensual basis for this. As Beyers (2013) notes, urban land restitution, though strategically important, has limited potential for restructuring the apartheid city, given that African households had never been fully integrated into South Africa's urban areas prior to their dispossession or removal. Redressing spatial segregation, therefore, requires a systematic national framework (Beyers, 2013). This section considers securing of urban land tenure and aspects of urban land redistribution that are not as yet fully addressed through the IUDF and SPLUMA. Mechanisms for moderating the property market cut across these two pillars of urban land reform.

\subsection{Securing tenure}

Securing land tenure and redistribution of land through effective access to well-endowed urban location cannot be separated, particularly as the effectiveness of redistribution may depend on appropriate forms of tenure. Individuals' and households' needs are diverse and change over time. Ensuring access thus means providing a variety of tenure and accommodation types. While the need for affordable rental (financially accessible to the very poor, and remaining so over time) is well acknowledged in urban policy; in practice, this is largely associated with apartment buildings. This presents challenges, as collective maintenance and management are required, on an ongoing basis and at a cost to the end-user. Long-term renting or leasing of small parcels of land with rights to invest in top structures or buildings must be included in the tenure options for the urban poor, particularly given the less costly legal procedure involved in allocation of leases when compared to titling under freehold tenure.

Collective forms of tenure such as shared ownership, Community Land Trusts (CLTs) and Community Property Associations (CPAs) have not received attention in urban policy (Klug \& Klug, 2019). CLTs remove portions of land from market processes to ensure continued affordability. They separate ownership of land from ownership of buildings on the land. The land is owned by the CLT, a registered non-profit corporation, which then grants the owner of the building a long-term ground lease for the building, or any other improvements on the land. This ensures that land parcels are held outside of the market in perpetuity by a trust that is in place to ensure ongoing affordability of the property for low-income users (Davis, 2011).

CLTs and CPAs may apply to land or to existing buildings, for instance in the inner city. In these instances, the building units may be under sectional title or share block, but they will exclude the underlying land parcel. Thus, the units will not be subjected to increasing land values, thereby keeping them affordable. For these and other inner-city regeneration options, innovative building rehabilitation incentive mechanisms need to be tested in the South African context. Property Rates Abatements provide abatement of all 
or part of the property rates arising from the increased value of the property that result from rehabilitation (Mallach, 2010). Rehabilitation Assistance provides financial assistance to developers of buildings requiring rehabilitation; funds are offered as grants or deferred loans or conventionally structured loans at below-market interest rates ${ }^{2}$ (Mallach, 2010). It is important to explore these mechanisms not only to retain well-located land and buildings for the public good, but also to ensure that they remain affordable for the poor over time, that is resilient to forces of gentrification. Communal forms of ownership and other alternatives provide useful options for tenure that ensure redistribution and asset transfer to the collective rather than the individual.

The creation of greater equity in the distribution of propertybased assets is important for an urban land-reform programme. In the context of a market-based society, where life opportunities are significantly shaped by asset ownership, land reform must involve expanding property ownership among those historically deprived. Therefore, ownership opportunities should still be provided alongside other tenure options. However, transferable top-structure assets on land held as individual leaseholds or collectively in community land trust should also be recognised as viable alternatives to assets invested on land held under freehold titles. Diverse approaches should include incremental approaches to tenure upgrades, with occupational rights given to vulnerable populations, followed where relevant by the invariably lengthier legal processes to upgrade tenure to standard forms. A wide range of financial access mechanisms in support of diverse tenure options is needed (including, for example, those that support CLTs and CPAs).

For households and individuals unable to make long-term

2 These financial instruments are currently applied in the USA, and would need to be redesigned for the South African legal context. locational commitments or unable to invest, there is a particular need for well-managed budget rental and other forms of cheap living such as individual rooms for rent, and overnight or weeknight accommodation. This is critical to enable access to livelihood opportunities, providing viable solutions to the cost of commuting, and securing alternatives to sleeping rough. A foothold for the poor in well-located areas can be facilitated through regulations that enable formal rights to the use of small spaces, even if the $\mathrm{m}^{2}$ price remains unmoderated. Extra-legal examples of this are evident in inner-city Johannesburg (CoJ), where apartment space is subdivided into affordable micro-portions, for instance an enclosed balcony or a portion of a sitting-room (Mayson \& Charlton, 2015). In addition, the creation of dignified spatial commons, for instance public spaces, and rights to use these, be this for productive purposes or even for sleeping, are also critical in providing access to well-located areas (Davy, 2009).

\subsection{Moderating interests invested in property}

The concern that the urban property market excludes the poor is well represented in the IUDF. How this may be moderated effectively is one of the biggest challenges for urban land reform. The insertion of tenure options, as proposed above, would be one important step, but this needs to be complemented with measures to re-orient property interests, in order to take account of responsibilities, as idealistic as this may seem. There are early indications from the South African Property Owners Association (SAPOA) and those involved in the property sector such as the Banking Association of South Africa, that there is a willingness to consider how state-private sector partnerships may work to achieve more equitable outcomes in the property market (SAPOA, 2007; SAPOA, 2018). However, redlining by financial institutions continues to prejudice well-located areas of the city that are undergoing transformation, for instance through extra-legal subdivision of living space. Redlining has not received policy or legislative attention since the shelving of the Community Reinvestment Bill of 2002.

Whereas developers and banks have resisted government attempts at enforcing inclusionary housing requirements, projects that target affordable or mixedincome housing in good locations are also opposed by the upper-l middle-class or the established working class, who perceive their own property interests undermined by such interventions. Political leadership must make clear that all segments of society and business must contribute to the process of urban spatial transformation, and that they will support state officials in their negotiations.

Individual property owners, including those in gated communities, must understand the social function of land. This has various implications. On the one hand, occupational rights, which have historically been regarded as inferior to ownership rights, will need to be recognised and respected (Van der Walt, 2009). On the other hand, property owners must recognise the share of responsibility of their local area for ensuring affordable and accessible housing and services and support integration by income and race. This could be part of a renewed national social compact. Subregional and local plans, which could be co-produced with communities, could explore where and how such housing could be accommodated within all suburbs, and how this would need to be supported. Whereas backyard rental accommodation is expanding most intensely in low-income townships, the more affluent and better located areas have the greatest capacity in terms of space, infrastructure and services to support intensification.

The opportunity for poorer people to live decently and affordably in well-located parts of the city and to make a living close to their places of residence is articulated in the consensus represented by the IUDF. However, the burden for provision 
of such opportunities for poorer people cannot effectively be carried by a few neighbourhoods. It has to be distributed fairly across towns and cities. In the United States of America (USA), the policy notion to "affirmatively further fair housing opportunities" (AFFH) has become an obligation on municipalities since the enactment of the Fair Housing Act in 1968, though found by the federal court to be enforceable only in 2009 (Allen, 2012: 206). The State of New Jersey pioneered 'fair share mechanisms', through which it required each locality to develop a plan for housing their 'fair Share' of their community's low-income households" (Squires, Friedman \& Saidat, 2005: 141). Davis (2006: 382) usefully defines 'fair share', as applied in the USA, as a mobility strategy for "opening up areas from which subsidised housing, rental housing or lower-cost housing of any kind has been excluded; and making every locality participate more equally in meeting a regional responsibility for providing such housing".

Achieving a more integrated city through the use of 'fair share' in the context of South Africa's extreme inequality and deep divisions does require a sensitive management of urban areas and the capacity to mediate the conflicts that may arise. One of the challenges, for example, is the differential capacity to afford the costs of living, including payment for services, in well-located areas. Addressing this concern is arguably best served by providing a wide range of accommodation and income-generating options in close proximity, with utilities cross-subsidised through free basic quotas, indigency programmes, and sliding payment scales.

In South African cities, a 'fair share' approach aligns closely with the 'spatial justice' principle of SPLUMA (section 7a), and could form one basis for meeting the constitutional requirement for the state "to foster conditions which enable citizens to gain access to land on an equitable basis" (RSA, 1996, S25.5) in the urban context. "Affirmatively furthering fair housing opportunities" would require municipalities to actively promote accessible forms of accommodation across all suburbs. This could be done in the context of spatial frameworks and local plans where planners' and residents' associations explore the potential for accessible housing in each suburb and negotiate over the form it might take in a particular area. Various types of accommodation can form part of the deliberation at both municipal and suburb level.

An existing subsidy instrument that could be employed to support a fairer distribution of affordable housing is social housing, which remains underused in South Africa, as small delivery numbers testify. By 2014, approximately 50000 state-supported social housing units had been delivered countrywide, in comparison to 2.8 million "completed houses and units" in total (RSA, 2014: 68). Under the Social Housing Act, No. 16 of 2008 , urban restructuring zones are a mechanism to incentivise (through additional grants) the production of social housing in locations that would assist with all aspects of integration. However, these have also been severely underutilised (HDA \& NASHO, 2013).

A regulatory mechanism to ensure mixed income developments is inclusionary housing (requiring developers to incorporate a percentage of low-income units in all developments). Whereas the IUDF calls for a "national policy on inclusionary housing" (CoGTA, 2016: 66), there is still no national legislation in place. This gap hampers municipal initiatives. Developers compelled by one municipality's inclusionary housing regulations still have the option to invest in exclusionary developments in adjacent municipalities that do not impose such requirements. This immediately undermines inclusionary intentions and longer term objectives such as compaction.

Third is rental housing, with approaches required for the public and private sectors to facilitate this form of accommodation in affordable ways. For the non-public sector, supply-side subsidies should be explored, in order to assist owners of buildings in providing low-cost rental units. This also applies to student rental accommodation in key locations, although this should not be at the expense of housing opportunities for other economically weak individuals or households. Further subsidies, beyond existing state grants, are also needed to expand the severely limited supply of very cheap rental rooms currently being achieved by not-for-profit agencies such as social housing providers (Rebelgroup, 2016). These forms of rental housing provision are currently not subsidised or are inadequately covered by the existing subsidy mechanism for social housing (Rebelgroup, 2016). At the same time, targeted demandside vouchers, allowing poor households to rent accommodation, for instance in areas close to good schools, could be considered, but with careful assessment of the impact this may have on the pricing of rents in the market. The discussion about operational, in addition to capital subsidies for affordable rental accommodation also needs to be re-opened.

As mentioned earlier, affordable backyard accommodation, which is most prevalent in low-cost townships, should also feature more prominently across well-endowed neighbourhoods as a starting point to overcome socio-spatial inequalities. Government has remained ambivalent (and, at times, hostile) to this form of accommodation, as it flouts the urban order sought through new formal township development (Rubin \& Charlton, 2019). However, this attitude defies the reality of need and the practicality of this housing solution. Mechanisms to encourage liveable backyard accommodation (particularly in the previously 'White' suburbs) and to support the progressive improvement of this accommodation should be further developed and could include rates rebates for property owners 
who provide affordable rental units. A reassessment of town planning and building standards is needed to enable the entry of the poorest segments of the population into the backyard accommodation, while maintaining minimum essential health and safety standards, and allowing for the progressive upgrading of these standards. Increased densities must be supported through increased infrastructure capacity, including the social infrastructure that poorer households will require.

In addition, very low-cost overnight accommodation and budget housing for workers, working households and job seekers should also be distributed in fair share across all localities. The need for this arises, for instance, from individuals reclaiming recyclables in suburban areas who, in some cases, have regular accommodation on the periphery of the city, but need short-term well-located overnight accommodation to complete their work rounds (Charlton, 2018). Provision of such accommodation requires support by both state and private sector, recognising the low incomes of many urban dwellers and the high cost of urban living.

\section{The upgrading of informal settlements, wherever geotechnically feasible, should also be embraced and fast-tracked in all localities, as required under the Upgrading of Informal Settlements Programme (which treats relocation as a last resort), and under the spatial justice principles in SPLUMA. The recent roll-out of the National Upgrading Support Programme (NUSP) in situ upgrading training programme to local and provincial authorities is a gradual realisation that an upgrading approach has to be applied together with new models of partnering with communities, including host communities.}

\footnotetext{
Affordable premises for small business are also relevant to 'fair share' or spatial justice approaches to the property market. In practice, this may involve how small-scale and micro-enterprises can be included in and around retail and commercial
}

developments, and how these can articulate with accommodation opportunities, public transport as well as shared facilities and amenities.

While regulation, incentives and disincentives may be necessary to ensure a fair distribution of accessible housing, the USA experience with fair housing obligations showed that it is also important to "infuse the entire housing community" towards accepting the necessity of these measures for the sake of long-term social sustainability (Allen, 2012: 207). While the NDP proposed negotiated social, business and neighbourhood charters/compacts (NPC, 2012), embedding change in the wider psyche, the impacts of such undertakings would need to be monitored and more stringent measures introduced if the promised results are not yielded, while also avoiding destructive forms of social conflict. Important in this regard are consistent urban management approaches that prioritise the maintenance of health and safety across the board, rather than only for the upper-/middle-class and private investors (which often leads to the displacement of the poor through evictions and more subtle processes).

\subsection{Redistribution in an urban context}

Since the adoption of the NDP, SPLUMA and the IUDF, the South African state has embarked on mega-human settlements projects that contradict the agreed spatial vision of urban compaction (Ballard, Dittgen, Harrison \& Todes, 2017; Ballard \& Rubin, 2017). If urban land reform is framed as the creation of new towns or megacities, or largescale rapid land release, low-density sprawl may be increased, since it is generally only on the periphery that sufficient land is available for large-scale development. While such strategies can increase the quantity of property ownership through the creation of new erfs, these are likely to take years or decades to become desirable or competitive forms of property, if ever. If urban land reform is to be taken seriously, state-subsidised housing programmes that promote further urban dysfunctionality through, for example, release of land beyond the existing urban edge and in places distant from existing economic opportunity and viable public transport, should be immediately discontinued. By contrast, projects on well-located land held by the state should be encouraged, as suggested in the Panel report (RSA, 2019).

An urban land-reform programme cannot only focus its redistributional aspect on state land. The starting point must be the most appropriate land for inclusionary development, whether held in state or private hands. Redistribution cannot only be about the quantity of land, but also about the inherent social and commodity value of the land that is made available for occupation and/or ownership. Providing land along transit corridors, around development nodes, and within suburban environments, where there is a strong infrastructural base, will make a more meaningful contribution to the reduction of poverty and inequality than redistributing large tracts of peripheral land. Similarly, income-generating opportunities must be considered and maximised. This, in turn, depends on where the land is located.

With respect to private land portions, mechanisms to bring these onto the market to enable acquisition and redistribution of assets include rates surcharges on strategically located vacant land. Selective expropriation of particular properties is an option for securing well-located urban land for the poor. At least two if not three of the proposed categories of land for 'expropriation without compensation', as set out in the new Draft Expropriation Bill 2019 (published on 21 December 2018), could be applied within urban areas. The category of 'abandoned properties' would mainly apply to older, central urban areas, where buildings have been abandoned or not maintained by the owners. In many cases, these buildings are in such rates arrears that they could be legitimately 
expropriated without compensation.

Further categories include properties owned by state-owned enterprises such as Eskom, and finally, where land is held for purely speculative purposes, a category where mechanisms to incentivise or compel development with inclusionary dimensions over the short or medium term could be instituted.

Existing or well-located land that requires redevelopment could be used as a bargaining chip to reinforce and shape current private developer interest in providing lower middleincome rental housing in well-located areas, which is a growing trend, for which there is considerable demand (Harrison, 2016; Todes \& Robinson, 2019). In these contexts, the state could offer land as part of partnership arrangements, in which case it could be used by the public sector to encourage such developers to move further down the incomerental market ladder and to shape the design of such development (towards more mixed use, active street frontage, and so on).

\section{IMPLICATIONS FOR URBAN PLANNING}

There are several mechanisms currently in place that allow many aspects of land reform to proceed in the short term. Several of the provisions in South African planning legislation and urban policy have as yet not been adequately explored or tested. A careful audit could identify both underutilised instruments and gaps in the existing framework (for example, around inclusionary housing and anti-redlining) and these should be the focused target of further legislation. An audit could include the assessment of pilot projects and lessons learnt from municipal experimentation. Mechanisms such as proactive landuse rezoning have been proposed in the case of Johannesburg's Corridors of Freedom Programme. This was intended to enable rapid rezoning of land towards higher density, facilitating the delivery of affordable housing. However, the use of this mechanism has been constrained by changing priorities linked to a political shift from an ANC to a DA-EFF coalition, which resulted in the redirecting of funding away from the Corridors. Nevertheless, the Programme did include significant engagement with the private sector, which influenced what and how they developed in the area (Todes \& Robinson, 2019). Further experimentation should be encouraged with bold and innovative policy initiatives.

\section{Responsibility for urban} transformation lies not solely with government, but also with all segments of society. Negotiation concerning particular initiatives and forms of policy implementation can be healthy, but it needs to take place within a clear overarching framework and commitment to an urban land transformation. This requires particular skills of planners, especially in the public sector. A major risk has to do with the capacity of the state, across all scales, to handle an ambitious programme of urban transformation both administratively and in terms of the relational aspects, that is the capacity to negotiate, deal with conflict, and forge common societal visions. Although the building of capacity is a gradual process, it has to be pursued with determination. Capacity is also required in relation to preventing and fighting corruption, one of the continued threats to the credibility and success of any landreform programme, and one in which planners in various roles have been implicated (Olver, 2017; Olver, 2018).

\section{CONCLUSIONS}

Urban land is unquestionably a critical element of the larger landreform debate and, given the current rates of urbanisation, will become more important into the future. If equity, spatial and social justice are to be achieved, then the primacy of this land and its contribution to lives of the poorest urban dwellers not only needs to be recognised but actions need also to be taken. Much of the scaffolding already exists, in principle and policy. However, these need to be extended and put into practice. This will require a shift in mindset across society, better capacity in the state, and a reconsideration of the value of land.

Crucially, however, a strong message is needed on the importance of urban land reform, the overarching vision and framework within which it can be guided, and the positive benefits it can have for society. Importantly, the various instruments to promote urban land reform need to be explored and piloted as soon as possible to begin the difficult task of changing mindsets within all segments of our society, to the benefits of urban land reform.

Urban land reform is more likely to deliver hoped for benefits if it is viewed as part of a multifaceted strategy that provides the necessary social and physical infrastructure (including well-designed public spaces) to accommodate greater densities, and pays attention to issues of urban management and safety. In this regard, one needs to move beyond an approach that might treat urban land reform as another siloed intervention.

\section{REFERENCES}

ALLEN, A. 2012. Fair Housing Act. In: Carswell, A. (Ed.). The Encyclopedia of housing. $2^{\text {nd }}$ edition. London: Sage, pp. 203-207.

ANC (AFRICAN NATIONAL CONGRESS). 1994. Reconstruction and development programme. Johannesburg: African National Congress.

BALLARD, R., DITTGEN, R., HARRISON, P. \& TODES, A. 2017. Megaprojects and urban visions: Johannesburg's corridors of freedom and Modderfontein. Transformation: Critical Perspectives on Southern Africa, 95(1), pp. 111-139.

BALLARD, R. \& RUBIN, M. 2017. A 'Marshall Plan' for human settlements: How megaprojects became South Africa's housing policy. Transformation: Critical Perspectives on Southern Africa, 95(1), pp. 1-31. 
BERTAUD, A. 2015. The spatial distribution of land prices and densities: The models developed by economists. Working Paper 33. New York: New York University.

BEYERS, C. 2013. Urban land restitution and the struggle for social citizenship in South Africa. Development and Change, 44(4), pp. 965-989.

BREMNER, L. 2000. Post-apartheid urban geography: A case study of Greater Johannesburg's Rapid Land Release Programme. Development Southern Africa, 17(1), pp. 87-104.

BUSINESSTECH. 2018a. Five areas in Gauteng that are currently subject to the EFF's land grabs. BusinessTech, 14 March. [Online]. Available at: <https://businesstech.co.za/news/ government/231543/5-areas-ingauteng-that-are-currently-subjectto-the-effs-land-grabs/> [Accessed: 20 June 2019].

BUSINESSTECH. 2018b. How the DA would like to deal with land redistribution if it was in charge. BusinessTech, 12 March. [Online]. Available at: <https://businesstech co.za/news/government/231079/ how-the-da-would-deal-with-landdistribution-if-it-was-in-charge/> [Accessed: 20 June 2019].

CAHF (CENTRE FOR AFFORDABLE HOUSING FINANCE IN AFRICA). 2019. From counting houses to making houses count: Publicly available administrative data on subsidised housing. CAHF. [Online]. Available at: <https://housingfinanceafrica. org/app/uploads/publicly-availableadministrative-data-on-subsidisedhousing-final-30-sept-2019-CG.pdf> [Accessed: 4 November 2019].

CHARLTON, S. 2018. Spanning the spectrum: Infrastructural experiences in South Africa's state housing programme. International Development Planning Review, 40(2), pp. 97-120.

CITIES ALLIANCE. 2010. The city statue of Brazil: A commentary. São Paulo: Cities Alliance and Ministry of Cities, Brazil.

\section{COGTA (COOPERATIVE} GOVERNANCE AND TRADITIONAL AFFAIRS). 2016. Integrated urban development framework: A new deal for South African cities and towns. Pretoria: Department of Cooperative Governance and Traditional Affairs.
COJ (CITY OF JOHANNESBURG). 2019. Inclusionary housing: Incentives, regulations and mechanisms. Johannesburg: City of Johannesburg.

DA (DEMOCRATIC ALLIANCE). [n.d.]. 'Our Land Reform Plan'. Democratic Alliance Website. [Online]. Available at: $<$ https://www.da.org.za/our-land-reformplan> [Accessed: 24 October 2019].

DAVIS, J.E. 2006. Between developing and the deep blue see: What's a city or state to do? In: Bratt, R., Stone, M. \& Hartman, C. (Eds). A right to housing: Foundation for a new social agenda. Philadelphia, PN: Temple University Press, pp. 364-398.

DAVIS, J.E. 2011. Origins and evolution of the community land trust in the United States. In: White, K. (Ed.). The CLT technical manual. Portland, OR: National Community Land Trust Network, pp. 3-47.

DAVY, B. 2009. The poor and the land: Poverty, property and planning. Centenary Paper. Town Planning Review, 30(8), pp. 227-264.

FERNANDES, E. 2002. Providing security of land tenure for the urban poor: The Brazilian experience. In: DurandLasserve, A. \& Royston, L. (Eds). Holding their ground: Secure land tenure for the urban poor in developing countries. London: Earthscan, pp. 101-126.

GLAESER, E. 2010. Agglomeration economies. Chicago, ILL: University of Chicago Press.

\section{GUO, C., BUCHMANN, C. \&} SCHWARZ, N. 2019. Linking urban sprawl and income segregation: Findings from a stylized agent-based model. Environment and Planning B, 46(3), pp. 469-489.

HABITAT III. 2016. New urban agenda. New York: United Nations.

HARRISON, K. 2016. The corridors of freedom: The developer, the planner and the public realm. Report for Agence France Développement and City of Johannesburg, University of the Witwatersrand, Johannesburg.

HARRISON, P., TODES, A. \& WATSON, V. 2008. Planning and transformation: Learning from the post-apartheid experience. London: Routledge.
HDA (HOUSING DEVELOPMENT AGENCY) \& NASHO (NATIONAL ASSOCIATION OF SOCIAL HOUSING ORGANISATIONS). 2013. Reviving our inner cities: Social housing and urban regeneration in South Africa. Research report. Research series published by the Housing Development Agency. [Online]. Available at:<http:// thehda.co.za/pdf/uploads/multimedia/ HDA_NASHO_reseach_report_lo-res. pdf> [Accessed: 5 June 2019].

\section{HSF (HELEN SUZMAN}

FOUNDATION). [n.d.]. About HSF. Helen Suzman Foundation Website.

[Online]. Available at: <https:// hsf.org.za/about/about-the-helensuzman-foundation> [Accessed: 29 October 2019].

HORNBY, D., KINGWELL, R., ROYSTON, L. \& COUSINS, B. 2017. Untitled: Securing land tenure in urban and rural South Africa. Durban: University of KwaZulu-Natal Press.

KEPE, T. \& HALL, R. 2016. Land, politics and policy change in South Africa: What questions for land redistribution policy and practice? In: Kepe, T., Levin, M. \& von Lieres, B. (Eds). Domains of freedom: Justice, citizenship and social change in South Africa. Cape Town: UCT Press, pp. 85-104.

KLUG, H. \& KLUG, N. 2019.

Community land trusts and social inclusion. In: Bénit-Gbaffou, C., Charlton, S., Didier, S. \& Dörmann, K. (Eds). Politics and community-based research. Perspectives from Yeoville Studio. Johannesburg: Wits University Press, pp. 179-199.

LEFEBVRE, H. 1996/1968. Writings on the city. Oxford: Blackwell.

LI, T., LI, W. \& QIAN, Z. 2010. Variations in ecosystem service value in response to land use changes in Shenzhe. Ecological Economics, 69(7), pp. 1427-1435.

MALLACH, A. 2010. Bringing buildings back: From abandoned properties to community assets. $2^{\text {nd }}$ edition. Montclair, NJ: National Housing Institute.

MARAIS, L. \& CLOETE, J. 2015.

Financed homeownership and economic downturn in South Africa. Habitat International, 50, pp. 261-269. 
MARX, C. \& RUBIN, M. 2008. 'Divisible spaces': Land biographies in Diepkloof, Thokoza and Doornfontein, Gauteng.

A final draft report prepared for Urban LandMark.

MASSYN, M., MCGAFFIN, R., VIRULY, F. \& HOPKINS, N. 2015. The challenge of developing higher density affordable housing in the inner city of Cape Town. International Journal of Housing Markets and Analysis, 8(3), pp. 412-428.

MAYSON, S. \& CHARLTON, S. 2015. Accommodation and tenuous livelihoods in Johannesburg's inner city: The 'Rooms' and 'Spaces' typologies. Urban Forum, 26(3), pp. 343-372.

MKHIZE, N. 2015. The politics of urban land and ownership: Locating spatial transformation in the urban land question. The Urban Land Paper Series, Volume I, pp. 1-9. [Online]. Available at: <http://www.sacities.net/ wp-content/uploads/2015/10/UrbanLand-Series-Vol-1-SACN-2015.pdf> [Accessed: 5 June 2019].

MORAPELA, K. 2018. What is the urban land question? A presentation at the Thought Leader Series at the University of the Free State, 30 July. [Online]. Available at: <https://www.ufs. ac.za/docs/default-source/ufs-newslist/kgotso-morapela-presentation. pdf?sfvrsn=a6f2b821_0> [Accessed: 21 June 2019].

MPOFU, B. 2017. The urban land question, land reform and the spectre of extrajudicial land occupations in South Africa. Africa Insight, 46(4), pp. 96-111.

NICOLSON, G. 2018. Gauteng Premier's land release plans are politically attractive, practically difficult. Daily Maverick, 18 May. [Online]. Available at: <https://www. dailymaverick.co.za/article/2018-05-18gauteng-premiers-land-release-plansare-politically-attractive-practicallydifficult/> [Accessed: 12 June 2019].

NPC (NATIONAL PLANNING COMMISSION). 2012. Our future Make it work. National Development Plan 2030. Pretoria: The Presidency.

OLVER, C. 2017. How to steal a city: The battle for Nelson Mandela Bay - An inside account. Johannesburg: Jonathan Ball.
OLVER, C. 2018. Patronage and politics in a South African city: A case study of Nelson Mandela Bay. Area Development and Policy, 3(3), pp. 275-292.

ORTHOPHER, A. 2016. Wealth inequality in South Africa: Evidence from survey and tax data. REDI3X3 Working Paper series at the University of Cape Town. [Online]. Available at: $<$ http://www.redi3x3.org/paper/wealthinequality-south-africa-evidencesurvey-and-tax-data> [Accessed: 25 October 2019].

REBELGROUP. 2016. Johannesburg Inner City Housing Strategy \& Implementation Plan 2014-2021 strategy and programmes, prepared for the City of Johannesburg. [Online]. Available at: <http://nu.org.za/ wp-content/uploads/ICHIP-Strategyand-Programmes-April-2016.pdf> [Accessed: 30 May 2019].

ROYSTON, L. \& EBRAHIM, T. 2019. Urban land reform: Start with informal settlements. Daily Maverick, 4 July. [Online]. Available at: <https://www. dailymaverick.co.za/article/2019-07-04urban-land-reform-start-with-informalsettlements/> [Accessed: 14 May 2019].

RSA (REPUBLIC OF SOUTH AFRICA). 1996. The Constitution of the Republic of South Africa (Act 108 of 1996). Pretoria: Government Printers.

RSA (REPUBLIC OF SOUTH AFRICA). 2013. Spatial Planning and Land Use Management Act, Act no. 16 of 2013. Pretoria: Government Printers.

RSA (REPUBLIC OF SOUTH AFRICA). 2014. Twenty-year review. South Africa 1994-2014. The Presidency, Pretoria: Republic of South Africa.

RSA (REPUBLIC OF SOUTH AFRICA). 2019. Final Report of the Presidential Advisory Panel on Land Reform and Agriculture. For His Excellency the President of South Africa. Pretoria: Republic of South Africa.

RUBIN, M. \& CHARLTON, S. 2019 State-led housing provision twenty years on: Change, evolution and agency on Johannesburg's edge. In: Keil, R., Üçoğlu, M. \& Guney, M. (Eds). Massive suburbanization: (Re) Building the global periphery one large-scale housing project at a time. Toronto: University of Toronto Press, pp. 241-266.
SACN (SOUTH AFRICAN CITIES NETWORK). 2015. Urban Land Paper Series Volume 1. South African Cities Network, Johannesburg. [Online]. Available at: <http://www.sacities.net/ wp-content/uploads/2015/10/UrbanLand-Series-Vol-1-SACN-2015.pdf> [Accessed: 14 May 2019].

SAPOA. 2007. SAPOA. All for Inclusionary Housing, Public Comment, Property24, $12^{\text {th }}$ April 2007. [Online]. Available at: <https://www. property24.com/articles/sapoa-all-forinclusionary-housing/5081> [Accessed: 18 June 2019].

SAPOA. 2018. SAPOA Comments on the City of Johannesburg Draft Inclusionary Policy, SAPOA News, 23rd April 2018. [Online]. Available at: $<$ http://www.sapoa.org.za/media/pressreleases/sapoa-comments-on-the-cityof-johannesburgs-draft-inclusionaryhousing-policy/> [Accessed: 18 June 2019].

SHISAKA. 2004. Workings of township residential property markets. A research project sponsored by the FinMark Trust, Ford Foundation, Micro Finance Regulatory Council/ USAID, South African National Treasury and the National Housing Finance Corporation. Johannesburg: Shisaka. [Online]. Available at: <http:// housingfinanceafrica.org/app/uploads/ TRPMPhase3_Report.pdf> [Accessed: 5 June 2019].

SIMKINS, C. \& FONKAM, A. 2018. Human settlements and urban land reform, a report of the Helen Suzman Foundation. [Online]. Available at: $<$ https://hsf.org.za/publications/ special-publications/hsf-urbanisationjune-2018.pdf> [Accessed: 12 April 2019].

\section{SOUTH AFRICAN MARKET}

INSIGHTS. 2019. South Africa's population density map. Category: Socio-economics. [Online]. Available at: <https://www.southafricanmi. com/population-density-map.html> [Accessed: 20 June 2019].

SQUIRES, G., FRIEDMAN, S. \& SAIDAT, C. 2005. Experiencing residential segregation: A contemporary study of Washington, D.C. In: Varady, D. (Ed.). Desegregating the city: Ghettos, enclaves and inequality. New York: State University of New York Press, pp. 127-144. 
STATS SA. 2010. Data concepts and definitions for statistics South Africa, 2010, Version 3. Pretoria: Statistics South Africa. [Online]. Available at: <http://www.statssa. gov.za/standardisation/Concepts and_Definitions_\%20StatsSAV3.pdf> [Accessed: 28 October 2019].

STATS SA. 2017. Poverty trends in South Africa: An examination of absolute poverty between 2006 and 2015. Pretoria: Statistics South Africa. [Online]. Available at: <http://www.statssa.gov.za/publications/ Report-03-10-06/Report-03-10-062015. pdf> [Accessed: 20 June 2019].

TODES, A. \& ROBINSON, J. 2019. Re-directing developers: New models of rental housing development to re-shape the post-apartheid city? Environment and Planning A. Economy and Space, 3 September. DOI: https:// doi.org/10.1177/0308518X19871069

VAN DER WALT, A. 2009. Property in the margins. Portland, OR: Hart Publishing.

WATSON, V. 2009. 'The planned city sweeps the poor away...'. Urban planning and $21^{\text {st }}$ century urbanization. Progress in Planning 72, pp. 151-193.

WEBER, R. 2002. Extracting value from the city: Neoliberalism and urban redevelopment. Antipode, 34(3),

pp. 519-540. 